\title{
Locally Advanced Anaplastic Thyroid Carcinoma with Long-Term Survival of More Than 7 Years after Combined Surgery Including Tracheal Resection and Radiotherapy: Case Report
}

\author{
Weizhong Ernest Fu' ${ }^{*}$, Ming Yann Lim ${ }^{1}$, Khoon Leong Chuah ${ }^{2}$, Li-Chung Mark Khoo ${ }^{1}$ \\ ${ }^{1}$ Department of Otolaryngology, Tan Tock Seng Hospital, Singapore City, Singapore \\ ${ }^{2}$ Department of Pathology, Tan Tock Seng Hospital, Singapore City, Singapore \\ Email: ${ }^{*}$ ernest.fu@gmail.com
}

Received 8 May 2015; accepted 26 July 2015; published 29 July 2015

Copyright (C) 2015 by authors and Scientific Research Publishing Inc.

This work is licensed under the Creative Commons Attribution International License (CC BY). http://creativecommons.org/licenses/by/4.0/

(c) †) Open Access

\begin{abstract}
Background: Anaplastic thyroid carcinoma (ATC) is one of the most aggressive human malignancies with a mean survival time of 6 months regardless of treatment. Aim: To present a case of locally advanced anaplastic thyroid carcinoma with long-term survival. A 10-year literature review of locally advanced ATC with long-term survival (more than 2 years) is also presented. Case presentation: We present a case of locally advanced anaplastic thyroid carcinoma (ATC) with tracheal invasion in a 67-year-old elderly Chinese man who was treated with radical surgery encompassing total thyroidectomy, neck dissection and tracheal resection followed by adjuvant radiotherapy. Long-term disease-free survival is more than 7 years to date. Conclusion: The prognosis of ATC remains poor as it is characterized by aggressive and extensive disease at presentation, the inability in most patients to perform radical enough surgery in order to achieve clear margins, high morbidity of complete extirpation and limited response to radiotherapy or chemotherapy. However, if complete surgical resection is possible, patients should be treated aggressively with a combination of surgery and adjuvant radiotherapy.
\end{abstract}

\section{Keywords}

Anaplastic, Thyroid, Survival, Trachea

${ }^{*}$ Corresponding author.

How to cite this paper: Fu, W.Z.E., et al. (2015) Locally Advanced Anaplastic Thyroid Carcinoma with Long-Term Survival of More Than 7 Years after Combined Surgery Including Tracheal Resection and Radiotherapy: Case Report. International Journal of Otolaryngology and Head \& Neck Surgery, 4, 309-316. http://dx.doi.org/10.4236/ijohns.2015.44053 


\section{Introduction}

Anaplastic thyroid carcinoma (ATC) accounts for about $2 \%$ of all thyroid carcinomas and is one of the most aggressive human malignancies [1]-[4]. In most series, mean survival time from diagnosis is 6 months regardless of treatment [5]-[13]. Peak incidence is usually more than 60 years of age and it occurs more commonly in females than males. Patients usually present with symptoms of extensive local invasion such as pain, dysphagia, hoarseness, respiratory distress and a rapidly enlarging neck mass.

In this paper, we present a case of locally advanced ATC with trachea invasion in an elderly male that was treated with radical surgery and adjuvant radiotherapy with long-term disease-free survival of more than 7 years. A 10-year literature review of locally advanced ATC with long-term survival (more than 2 years) is also presented.

\section{Case report}

A 67-year-old Chinese man first presented to us with a left sided neck mass of 2 months' duration associated with hoarseness and compressive symptoms since 1 month.

He was a smoker and had a history of bilateral pulmonary silicosis, having previously worked in a granite quarry for more than 25 years. He has no family history of thyroid disease or previous exposure to irradiation.

On examination, there was a hard $4 \mathrm{~cm}$ left thyroid mass that was fixed to the larynx and trachea. There were no palpable cervical nodes. Nasoendoscopy examination revealed left vocal cord paresis in the adducted position. Computed tomography (CT) revealed a left thyroid lesion with possible tracheal invasion (Figure 1). The left vocal fold was adducted. There were no evidence of metastatic cervical lymphadenopathy and systemic examination was negative for distant metastasis. Fine-needle aspiration cytology (FNAC) showed features of a highgrade malignant tumour with necrosis favouring an anaplastic carcinoma of the thyroid. Thyroid function tests were normal.

He underwent elective total thyroidectomy, bilateral level 6 neck dissection, and tracheal resection with primary end-to-end anastomosis. There was frank tracheal invasion with gross tumour seen intra-luminally. Frozen section analysis showed a malignant high-grade neoplasm. The post-operative period was uneventful and he was discharged after 12 days.

Final histology showed anaplastic carcinoma of the isthmus and left hemithyroid measuring $5 \times 3.7 \times 2.5 \mathrm{~cm}$.

On microscopic examination, it was a high-grade neoplasm composed of epithelioid and spindle cells with marked anisonucleosis. Necrosis and mitotic activity including tripolar mitotic figures were present (Figure 2). The tumour had infiltrated posteriorly into the adjacent trachea reaching the connective tissue below the epithelial lining of the trachea and was $2 \mathrm{~mm}$ from the closest tracheal margin. No follicular or papillary component

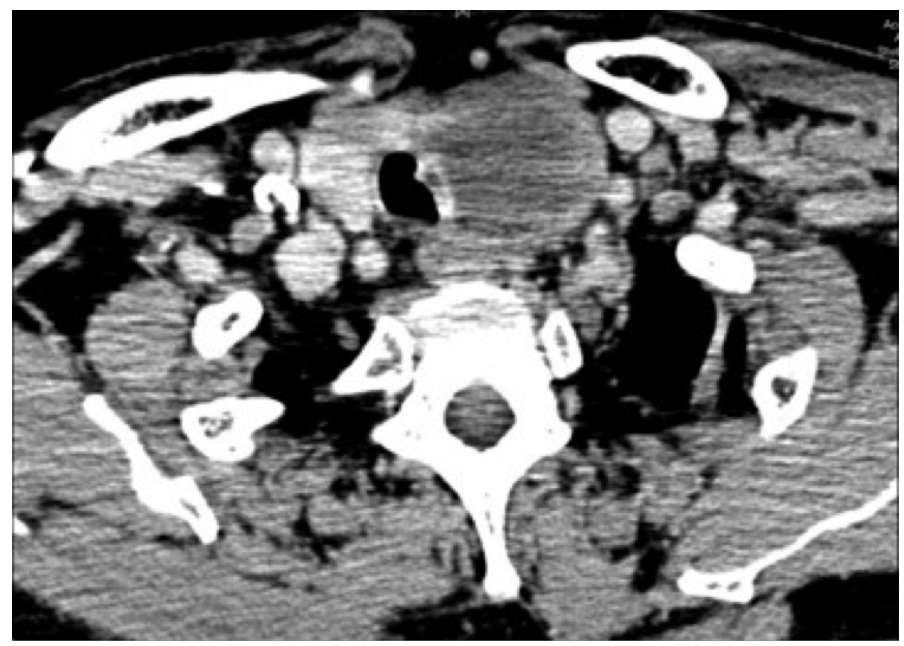

Figure 1. Hypodense left thyroid lesion $4.0 \times 3.9 \mathrm{~cm}$ causing displacement of the trachea to the right with invasion of left lateral wall of the trachea with a polypoidal enhancing mass of tissue seen protruding into the tracheal lumen. 


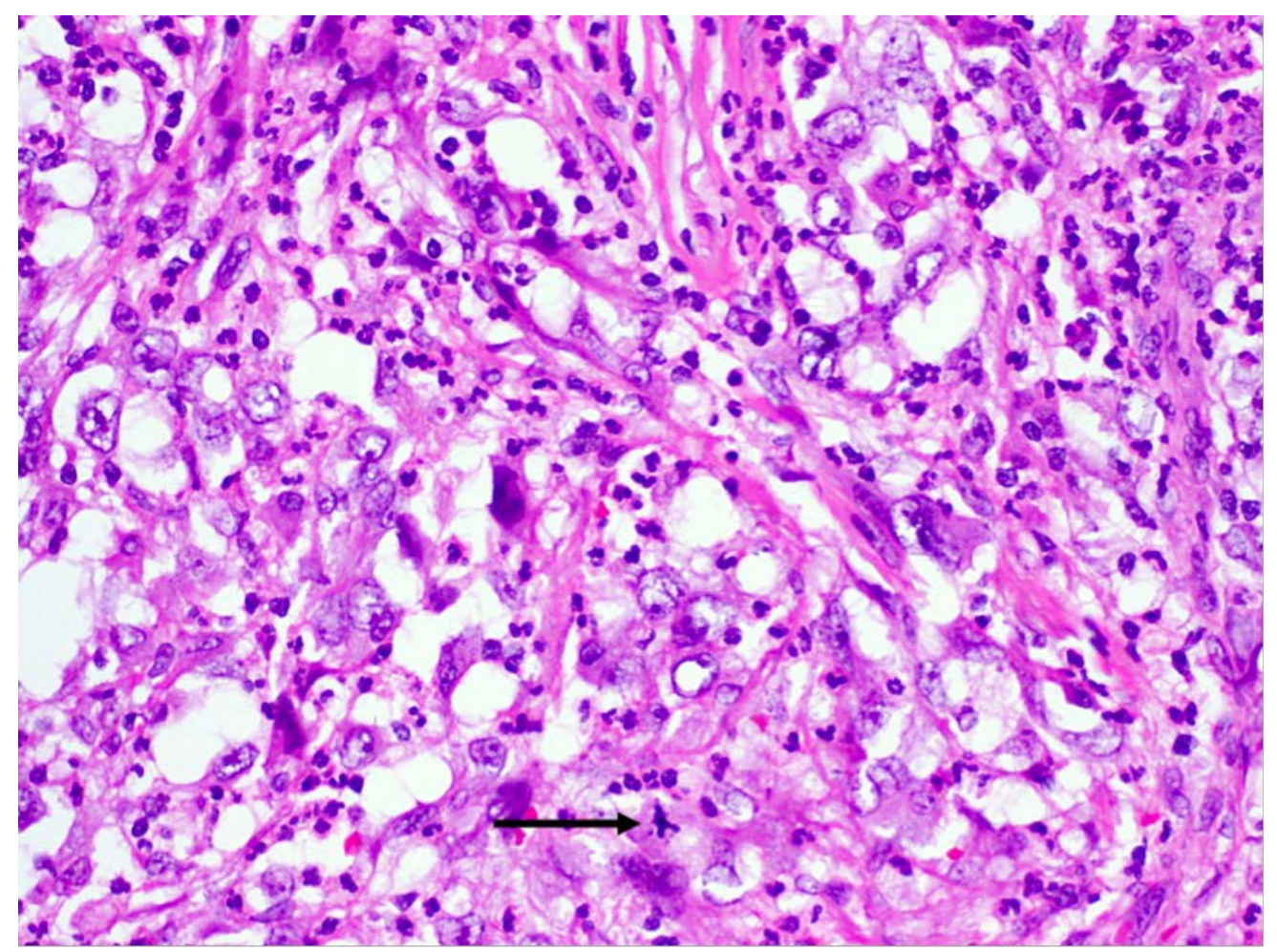

Figure 2. High-powered view of thyroid neoplasm disclosing a proliferation of epithelioid and spindle cells with nuclear pleomorphism amidst a fibrotic background. Note the presence of a tripolar mitotic figure (arrow). (Haematoxylin and eosin stain).

was noted despite extensive sampling. On immunohistochemistry, the tumour was positive for cytokeratin $\mathrm{AE}$ 1/3 but not CD31. A total of 11 level 6 lymph nodes were negative for tumour.

He subsequently underwent adjuvant intensity-modulated radiation therapy (IMRT) of 66 Gy over 33 fractions. He has since been on regular follow-up and to date has been disease-free for more than 7 years. Post-treatment CT scans has showed no evidence of local recurrence or distant metastasis. He is on thyroxine replacement.

\section{Discussion}

ATC is one of the most lethal human cancers and to date, the management remains challenging and controversial. Based on the American Thyroid Guidelines on ATC published in 2012 [14], in patients with extra-thyroidal invasion, an en bloc resection should be considered if grossly negative margins (R1 resection) could be achieved.

There have been many studies looking at various prognostic factors affecting survival. Kebebew et al. [5] studied a cohort of 516 patients with ATC wherein multivariate analysis showed that although most patients with ATC had an extremely poor prognosis, patients less than 60 years old with intra-thyroidal tumours survived longer. Surgical resection with external beam radiotherapy was associated with lower cause-specific mortality.

Other studies have variably shown that younger age, tumour size less than $6 \mathrm{~cm}$, localized disease, female gender, and tumour resectability are independent predictors of lower cause-specific mortality [8] [15]-[17]. In particular, complete surgical resection appears to be an important determinant of survival. Haigh et al. [18] reported that the primary factor associated with survival was potential curative surgery. In their study, neither tumour size nor age had influenced survival. Kobayashi et al. [19] also observed that complete tumour resection achieved better prognosis and that age did not significantly impact survival.

In contrast to the above findings, Sugitani et al. [9] performed a retrospective analysis of 44 patients with ATC and devised a novel prognostic index (PI) based on four prognostic factors to select patients for aggressive multimodal treatment. The features were the presence of acute symptoms, large tumour size $(>5 \mathrm{~cm})$, distant 
metastasis, and leukocytosis (white blood cell count $>10,000 / \mathrm{mm}^{3}$ ), but notably did not include complete surgical resection. The presence of acute symptoms and large tumour size probably reflect rapid disease progression. Smaller tumour size may correlate with resectability. Patients with distant metastasis inevitably do poorly and the presence of leukocytosis likely represent the late stage of specific subtypes of ATC secreting granulocyte colony-stimulating factor (G-CSF) or related cytokines. The PI is calculated by totaling the number of unfavourable prognostic factors a given patient possessed: 0 to 4 . The study showed that patients whose PI was $\leq$ s1 had a $62 \%$ survival rate at 6 months. No patients whose PI was $\geq 3$ survived more than 6 months and all patients whose PI was 4 died within 3 months. The authors also noted that the mean PI of the patients treated by multimodal therapy was 0.6 (either 0 or 1 ), whereas the PI of those who were not was 2.3 , and hence proposed that multimodal treatment be advocated for PI of $\leq 1$ while aggressive treatment is avoided when PI is $\geq 3$.

Orita et al. [20] recently published the prospective application of this PI in the treatment strategy of 74 patients with ATC. 6-month survival rates for PI $\leq 1$ and PI $\geq 3$ were $72 \%$ and $12 \%$, respectively. Both groups (P1 $\leq 1$ and $\geq 3$ ) demonstrated significantly better disease-specific survival as compared to the previous study above. Within each group, the survival rates did not differ between stages. The authors thus concluded that the PI is valid for anticipating prognosis and aiding timely decisions on treatment policy for ATC.

In the present case, long-term survival with no evidence of disease after 7 years is unusual, especially considering the presence of tracheal invasion. However, based on the above PI, he has a PI of 1 for tumour size, which indicated that he would have benefitted from the multimodal treatment he received.

In the past, there has been anecdotal evidence of cases of ATC with long-term survival. Since the mid-1980s, a group of poorly differentiated thyroid cancers (PDTC) has been recognized and considered to be tumours of biological aggressiveness intermediate between the more indolent well-differentiated thyroid carcinomas and ATC [21]. Historically, the distinction between poorly differentiated thyroid cancer (PDTC) and ATC has always been difficult. In our patient, there was no question that the tumour was an ATC.

We carried out a literature review of all ATC cases with survival greater than 2 years. Prior to review, we identified several features thought to influence survival as discussed above, namely age, tumour size, extent of tumour spread, adequacy of surgical resection, histopathology and neoadjuvant/adjuvant therapy. We restricted our review to papers published after January 1990. Exclusion criteria included papers not published in peerreviewed journals as well as any case series in which the prognostic factors for the longest surviving cases were not specified. Medical subject headings and main keywords used were: "undifferentiated”, “anaplastic” and "thyroid", with variants of the main keywords also applied.

The initial review yielded a total of 37 articles, 10 case reports and 21 case series. 13 case series were further excluded due to insufficient data. We further excluded 3 case reports and 1 case series with only intra-thyroidal ATC tumours (T4a) for ease of comparison. A total of 7 case reports and 7 case series remained for our review.

A total of 22 cases of locally advanced ATC (T4b) with long-term survival of more than 2 years were compiled from the remaining 14 articles (Table 1). The length of survival varied from more than 2 to 12 years. The age at diagnosis ranged from 26 to 85 years. 4 cases [22]-[24] were diagnosed with ATC incidentally after surgery for presumed benign thyroid disease. Of cases that were known, most did not present with acute symptoms, usually that of a rapidly enlarging neck mass. Only 3 cases [22] [25]-[26] had evidence of tracheal invasion while 1 case [27] had tumour extending to the cervical esophagus.

All cases received multi-modality treatment with most cases being treated with radical surgery followed by either concurrent chemoradiation or radiotherapy or radioactive iodine ablation. Only 3 cases [27]-[29] received neoadjuvant chemoradiation followed by surgery. The extent of thyroidectomy performed also differed and ranged from lobectomy to total thyroidectomy. All patients with clinically or radiologically positive cervical lymph nodes underwent neck dissections. Surgical resection included debulking surgery, macroscopically complete resections and microscopically complete resections. In general, most studies concluded that although the prognosis of most patients with ATC continues to be poor, complete resection combined with adjuvant chemotherapy and radiotherapy resulted in better survival.

There have been 3 cases with comparable survival in the literature with survival of more than 9, 10 and 12 years [23] [24]. All cases were characterized by having just an incidental focus of ATC within an otherwise well-differentiated thyroid carcinoma with limited extra-thyroidal spread. Our case however, was different as our patient presented with a gross ATC tumour with tracheal invasion and we were fortunate that the disease was still surgically resectable.

A widely cited staging system by Shin et al. [30] for papillary thyroid cancer is based on the depth of tracheal 
Table 1. Cases of locally advanced (T4b) ATC with long-term survival of $>2$ years.

\begin{tabular}{|c|c|c|c|c|c|c|c|c|c|c|c|}
\hline $\begin{array}{l}\mathrm{S} \\
\mathrm{N}\end{array}$ & Journal & $\begin{array}{l}\text { Age/ } \\
\text { Gende }\end{array}$ & ${ }_{\mathrm{r}}$ Presentation & Extent of surgery & $\begin{array}{l}\text { Positive } \\
\text { margins }\end{array}$ & $\begin{array}{l}\text { Neoadjuvant/ } \\
\text { Adjuvant } \\
\text { Therapy }\end{array}$ & $\begin{array}{l}\text { Tumour } \\
\text { size }(\mathrm{cm})\end{array}$ & $\begin{array}{l}\text { Formal } \\
\text { Histopathology }\end{array}$ & $\begin{array}{l}\text { Presence of } \\
\text { extrathyroidal spread } \\
\text { \& location }\end{array}$ & TMN Stage & $\begin{array}{l}\text { Length } \\
\text { eof } \\
\text { survival }\end{array}$ \\
\hline 1 & Kanaseki et al. [25] & ] $52 / \mathrm{F}$ & $\begin{array}{l}\text { Enlarging } \\
\text { anterior neck } \\
\text { mass with vocal } \\
\text { cord palsy }\end{array}$ & $\begin{array}{l}\text { TT with tracheal wall } \\
\text { resection } \\
\text { Interval upper } \\
\text { mediastinal LN } \\
\text { dissection }\end{array}$ & No & $\begin{array}{l}\text { Adjuvant } \\
\text { CTX followed } \\
\text { by CRT }\end{array}$ & $d_{\times 3.0}^{9.0 \times 6.5}$ & $\begin{array}{l}\text { ATC with } \\
\text { tracheal invasion } \\
\text { Positive superior } \\
\text { mediastinal LN }\end{array}$ & $\begin{array}{l}\text { Yes } \\
\text { Tracheal wall and } \\
\text { mediastinal LN }\end{array}$ & $\begin{array}{l}\text { Stage IVB } \\
\text { T4bN1bM0 }\end{array}$ & $0_{\text {years }}^{>2}$ \\
\hline 2 & $\begin{array}{l}\text { Shinohara et al. } \\
\text { [27] }\end{array}$ & $53 / \mathrm{F}$ & $\begin{array}{l}\text { Anterior neck } \\
\text { pain with left } \\
\text { thyroid nodule }\end{array}$ & $\begin{array}{l}\text { Total pharyngo- } \\
\text { laryngo-esophagectomy } \\
\text { with bilateral neck and } \\
\text { upper mediastinum LN } \\
\text { dissection }\end{array}$ & No & $\begin{array}{l}\text { Neoadjuvant } \\
\text { CTX followed } \\
\text { by RT } \\
\text { Tumour } \\
\text { regrowth on } \\
\text { MRI after RT, } \\
\text { proceeded } \\
\text { with surgery }\end{array}$ & d & $\begin{array}{l}\text { Tumour replaced by } \\
\text { granulation tissue } \\
\text { and necrosis, no } \\
\text { cancer cells } \\
\text { (ATC on initial } \\
\text { fine-needle } \\
\text { aspiration cytology) }\end{array}$ & $\begin{array}{l}\text { Yes } \\
\text { Cervical esophagus }\end{array}$ & $\begin{array}{l}\text { Stage IVB } \\
\text { T4bN0MO }\end{array}$ & $\begin{array}{l}>2 \\
\text { years }\end{array}$ \\
\hline 4 & Noguchi et al. [28] & $51 / \mathrm{M}$ & $\begin{array}{l}\text { Rapidly growing } \\
\text { right thyroid } \\
\text { nodule with mild } \\
\text { tenderness }\end{array}$ & $\begin{array}{l}\text { Right lobectomy with } \\
\text { right levels } 2 \text { - } 4 \text { and } \\
\text { level } 6 \text { ND with } \\
\text { intraoperative RT }\end{array}$ & No & $\begin{array}{l}\text { Oral valproic } \\
\text { acid daily } \\
\text { Neoadjuvant } \\
\text { CRT } \\
\text { Adjuvant } \\
\text { CTX }\end{array}$ & $\begin{array}{l}3 \times 4.1 \times \\
3.5 \\
\end{array}$ & $\begin{array}{l}\text { Tumour surrounded } \\
\text { by fibrous tissue } \\
\text { divided by thin ring } \\
\text { of PTC; } \\
\text { encapsulating } \\
\text { fibrous tissue } \\
\text { contained remnants } \\
\text { of ATC } \\
\text { LN: } 4 \text { out of } 26 \\
\text { positive }\end{array}$ & $\begin{array}{l}\text { Yes } \\
\text { Strap muscles }\end{array}$ & $\begin{array}{l}\text { Stage IVB } \\
\text { T4bN1M0 }\end{array}$ & $\begin{array}{l}>2 \\
\text { years }\end{array}$ \\
\hline 6 & Liu et al. [23] & $68 / \mathrm{M}$ & $\begin{array}{l}\text { Anterior neck } \\
\text { mass with } \\
\text { compressive } \\
\text { symptoms and } \\
\text { dyspnoea }\end{array}$ & $\begin{array}{l}\text { TT with removal of } \\
\text { enlarged LNs }\end{array}$ & No & Adjuvant RT & $5 \times 3 \times 4$ & $\begin{array}{l}\text { ATC } \\
\text { LN negative }\end{array}$ & $\begin{array}{l}\text { Yes } \\
\text { Strap muscles }\end{array}$ & $\begin{array}{l}\text { Stage IVB } \\
\text { T4bN0M0 }\end{array}$ & $\begin{array}{l}>10 \\
\text { years }\end{array}$ \\
\hline 7 & $\begin{array}{l}\text { Pichardo-Lowden } \\
\text { et al. [26] }\end{array}$ & $26 / F$ & $\begin{array}{l}\text { Rapidly growing } \\
\text { anterior neck } \\
\text { mass with } \\
\text { odynophagia and } \\
\text { voice change }\end{array}$ & $\begin{array}{l}\text { TT and left modified } \\
\text { radical ND }\end{array}$ & No & $\begin{array}{l}\text { Adjuvant } \\
\text { CRT }\end{array}$ & $5 \times 4$ & $\begin{array}{l}\text { Undifferentiated } \\
\text { carcinoma } \\
\text { LN negative }\end{array}$ & $\begin{array}{l}\text { Yes } \\
\text { Tracheal wall, strap } \\
\text { and } \\
\text { sternocleidomastoid } \\
\text { muscles, encasing left } \\
\text { internal jugular vein } \\
\text { and adhering to } \\
\text { common carotid } \\
\text { artery }\end{array}$ & $\begin{array}{l}\text { Stage IVB } \\
\text { T4bN0M0 }\end{array}$ & $\begin{array}{l}>2 \\
\text { years }\end{array}$ \\
\hline 8 & Akaishi et al. [24] & $48 / F$ & Not known & $\begin{array}{l}\text { Now known but } \\
\text { completely resected }\end{array}$ & No & No & $<5$ & $\begin{array}{l}\text { Incidental small } \\
\text { focus of ATC }\end{array}$ & $\begin{array}{l}\text { Yes } \\
\text { Not known }\end{array}$ & Stage IVB & $\begin{array}{l}>12 \\
\text { years } 7 \\
\text { months }\end{array}$ \\
\hline 9 & Akaishi et al. [24] & $68 / F$ & Not kwown & $\begin{array}{l}\text { Not known but } \\
\text { debulking done }\end{array}$ & $\begin{array}{l}\text { Not } \\
\text { known }\end{array}$ & $\begin{array}{l}\text { Adjuvant RT } \\
\text { and CTX }\end{array}$ & $<5$ & $\begin{array}{l}\text { Incidental small } \\
\text { focus of ATC }\end{array}$ & $\begin{array}{l}\text { Yes } \\
\text { Not known }\end{array}$ & Stage IVB & $\begin{array}{l}9 \\
\text { years }\end{array}$ \\
\hline 10 & Akaishi et al. [24] & $66 / F$ & Not known & $\begin{array}{l}\text { Not known but } \\
\text { completely resected }\end{array}$ & No & $\begin{array}{l}\text { Adjuvant RT } \\
\text { and CTX }\end{array}$ & $>5$ & ATC & $\begin{array}{l}\text { Yes } \\
\text { Not known }\end{array}$ & Stage IVB & $\begin{array}{l}>3 \\
\text { years }\end{array}$ \\
\hline & I Kihara et al. [32] & 82 & $\begin{array}{l}\text { Immobile thyroid } \\
\text { mass }\end{array}$ & $\mathrm{d}_{\text {Subtotal thyroidectomy }}$ & $\begin{array}{l}\text { Not } \\
\text { known }\end{array}$ & $\begin{array}{l}\text { Adjuvant } \\
\text { CRT }\end{array}$ & 4.9 & ATC & $\begin{array}{l}\text { Yes } \\
\text { Surrounding muscle }\end{array}$ & $\begin{array}{l}\text { Stage IVB } \\
\text { T4bN0M0 }\end{array}$ & $\begin{array}{l}6 \text { years } \\
4 \\
\text { months }\end{array}$ \\
\hline
\end{tabular}




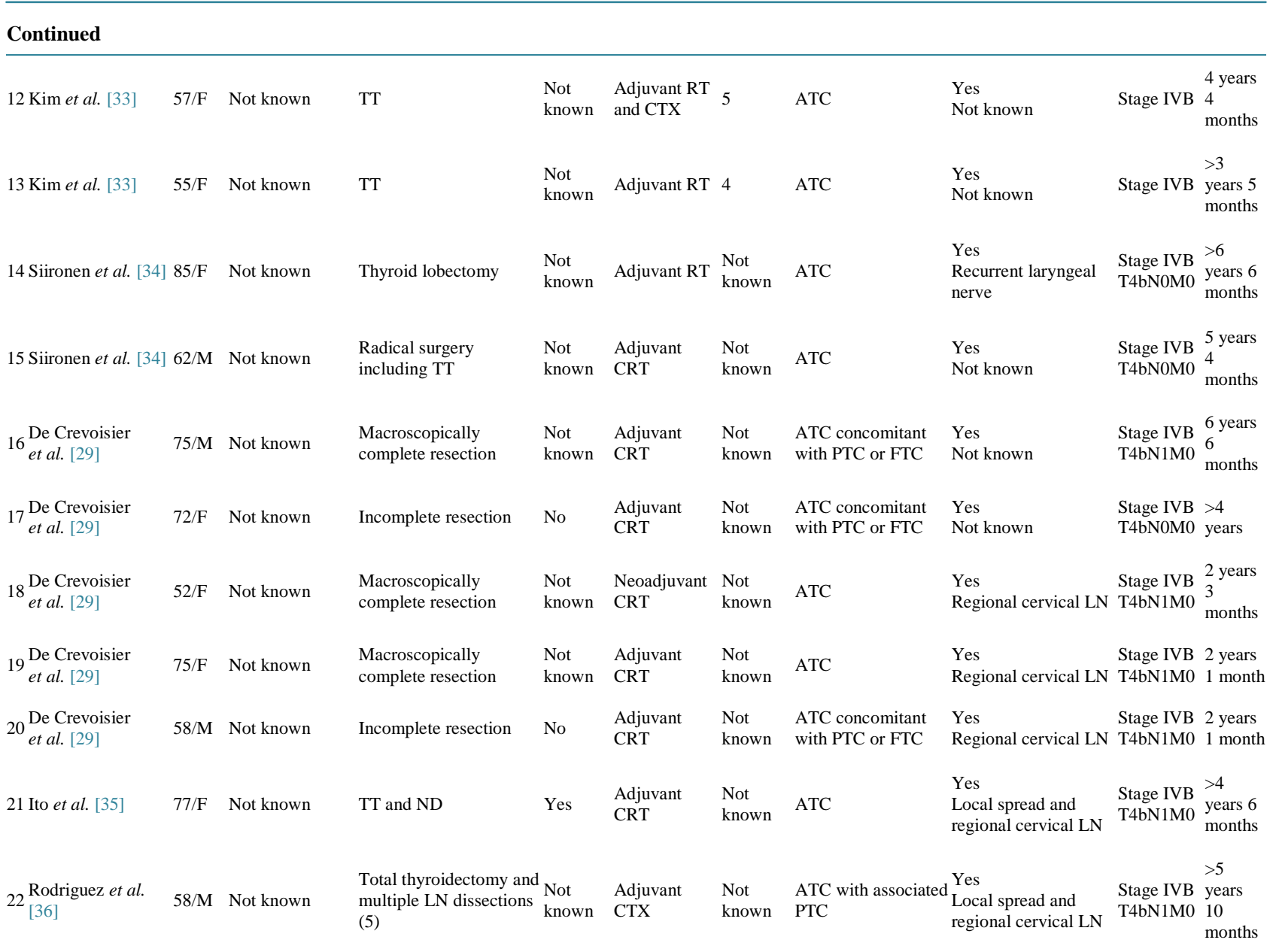

ATC: anaplastic thyroid carcinoma, CRT: concurrent chemoradiation, CTX: chemotherapy, FTC: follicular thyroid carcinoma, LN: lymph node, MRI: magnetic resonance imaging, ND: neck dissection, PTC: papillary thyroid carcinoma, RT: radiotherapy, TT: total thyroidectomy

invasion. Stage I disease abuts the external perichondrium of the trachea but without cartilaginous erosion. Stage II disease invades into the cartilage or causes cartilage destruction. Stage III disease extends into the lamina propria of the tracheal mucosa. Stage IV disease is full-thickness invasion through the tracheal mucosa. There is no similar staging system for ATC but based on the above, the degree of tracheal invasion for the present case would be classified as Stage 3. Based on the histological examination, the tumour was about $2 \mathrm{~mm}$ from the closest tracheal resection margin with tumour seen beneath the epithelium of the trachea. The involved tracheal segment was completely resected and primary anastomosis was performed.

Our case represents an anecdotal case wherein it is possible to achieve cure with clear surgical margins. Although there is general reluctance to attempt surgical resection in anaplastic carcinoma due to uniformly poor prognosis, our case concurs with the American Thyroid Guidelines on ATC [14] in which patients with ATC and extra-thyroidal invasion should have en bloc resection if grossly negative margins can be achieved. In our opinion, being able to achieve clear negative margins is the single most important prognostic factor for patients with ATC.

\section{Conclusion}

The prognosis of ATC remains poor as it is characterized by aggressive and extensive disease at presentation, the inability in most patients to perform radical enough surgery in order to achieve clear margins, high morbidity of complete extirpation and limited response to radiotherapy or chemotherapy. However, if complete surgical resection is possible, patients should be treated aggressively with a combination of surgery and adjuvant radiotherapy. 


\section{References}

[1] Pasieka, J.L. (2003) Anaplastic Thyroid Cancer. Current Opinion in Oncology, 15, 78-83. http://dx.doi.org/10.1097/00001622-200301000-00012

[2] Ain, K.B. (1998) Anaplastic Thyroid Carcinoma: Behavior, Biology, and Therapeutic Approaches. Thyroid, 8, 715-726. http://dx.doi.org/10.1089/thy.1998.8.715

[3] Giuffrida, D. and Gharib, H. (2000) Anaplastic Thyroid Carcinoma: Current Diagnosis and Treatment. Annals of Oncology, 11, 1083-1089. http://dx.doi.org/10.1023/A:1008322002520

[4] O’Neill, J.P., O’Neill, B., Condron, C., Walsh, M. and Bouchier-Hayes, D. (2005) Anaplastic (Undifferentiated) Thyroid Cancer: Improved Insight and Therapeutic Strategy into a Highly Aggressive Disease. Journal of Laryngology \& Otology, 119, 585-591. http://dx.doi.org/10.1258/0022215054516197

[5] Kebebew, E., Greenspan, F.S., Clark, O.H., Woeber, K.A. and McMillan, A. (2005) Anaplastic Thyroid Carcinoma. Treatment Outcome and Prognostic Factors. Cancer, 103, 1330-1335. http://dx.doi.org/10.1002/cncr.20936

[6] Goutsouliak, V. and Hay, J.H. (2005) Anaplastic Thyroid Cancer in British Columbia 1985-1999: A Population-Based Study. Clinical Oncology, 17, 75-78. http://dx.doi.org/10.1016/j.clon.2004.07.013

[7] Besic, N., Auersperg, M., Us-Krasovec, M., Golouh, R., Frkovic-Grazio, S. and Vodnik, A. (2001) Effect of Primary Treatment on Survival in Anaplastic Thyroid Carcinoma. European Journal of Surgical Oncology, 27, 260-264. http://dx.doi.org/10.1053/ejso.2000.1098

[8] McIver, B., Hay, I.D., Giuffrida, D.F., et al. (2001) Anaplastic Thyroid Carcinoma: A 50-Year Experience at a Single Institution. Surgery, 130, 1028-1034. http://dx.doi.org/10.1067/msy.2001.118266

[9] Sugitani, I., Kasai, N., Fujimoto, Y. and Yanagisawa, A. (2001) Prognostic Factors and Therapeutic Strategy for Anaplastic Carcinoma of the Thyroid. World Journal of Surgery, 25, 617-622. http://dx.doi.org/10.1007/s002680020166

[10] Passler, C., Scheuba, C., Prager, G., et al. (1999) Anaplastic (Undifferentiated) Thyroid Carcinoma (ATC). A Retrospective Analysis. Langenbeck's Archives of Surgery, 384, 284-293. http://dx.doi.org/10.1007/s004230050205

[11] Nilsson, O., Lindeberg, J., Zedenius, J., Ekman, E., Tennvall, J., Blomgren, H., et al. (1998) Anaplastic Giant Cell Carcinoma of the Thyroid Gland: Treatment and Survival over a 25-Year Period. World Journal of Surgery, 22, 725730. http://dx.doi.org/10.1007/s002689900460

[12] Junor, E.J., Paul, J. and Reed, N.S. (1992) Anaplastic Thyroid Carcinoma: 91 Patients Treated by Surgery and Radiotherapy. European Journal of Surgical Oncology, 18, 83-88.

[13] Demeter, J.G., De Jong, S.A., Lawrence, A.M. and Paloyan, E. (1991) Anaplastic Thyroid Carcinoma: Risk Factors and Outcome. Surgery, 110, 956-961.

[14] Smallridge, R.C., Ain, K.B., Asa, S.L., Bible, K.C., Brierley, J.D., Burman, K.D., et al. (2012) American Thyroid Association Anaplastic Thyroid Cancer Guidelines Taskforce. American Thyroid Association Guidelines for Management of Patients with Anaplastic Thyroid Cancer. Thyroid, 22, 1104-1139. http://dx.doi.org/10.1089/thy.2012.0302

[15] Venkatesh, Y.S., Ordonez, N.G., Schultz, P.N., Hickey, R.C., Goepfert, H. and Samaan, N.A. (1990) Anaplastic Carcinoma of the Thyroid: A Clinicopathologic Study of 121 Cases. Cancer, 66, 321-330. http://dx.doi.org/10.1002/1097-0142(19900715)66:2<321::AID-CNCR2820660221>3.0.CO;2-A

[16] Are, C. and Shaha, A.R. (2006) Anaplastic Thyroid Carcinoma: Biology, Pathogenesis, Prognostic Factors, and Treatment Approaches. Annals of Surgical Oncology, 13, 453-464. http://dx.doi.org/10.1245/ASO.2006.05.042

[17] Tan, R.K., Finley III, R.K., Driscoll, D., Bakamjian, V., Hicks Jr., W.L. and Shedd, D.P. (1995) Anaplastic Carcinoma of the Thyroid: A 24-Year Experience. Head Neck, 17, 41-47; Discussion 47-48. http://dx.doi.org/10.1002/hed.2880170109

[18] Haigh, P.I., Ituarte, P.H., Wu, H.S., Treseler, P.A., Posner, M.D., Quivey, J.M., et al. (2001) Completely Resected Anaplastic Thyroid Carcinoma Combined with Adjuvant Chemotherapy and Irradiation Is Associated with Prolonged Survival. Cancer, 91, 2335-2342. http://dx.doi.org/10.1002/1097-0142(20010615)91:12<2335::AID-CNCR1266>3.0.CO;2-1

[19] Kobayashi, T., Asakawa, H. and Umeshita, K. (1996) Treatment of 37 Patients with Anaplastic Carcinoma of the Thyroid. Head Neck, 18, 36-41. http://dx.doi.org/10.1002/(SICI)1097-0347(199601/02)18:1<36::AID-HED5>3.0.CO;2-\#

[20] Orita, Y., Sugitani, I., Amemiya, T. and Fujimoto, Y. (2011) Prospective Application of Our Novel Prognostic Index in the Treatment of Anaplastic Thyroid Carcinoma. Surgery, 150, 1212-1219. http://dx.doi.org/10.1016/j.surg.2011.09.005

[21] Patel, K.N. and Shaha, A.R. (2006) Poorly Differentiated and Anaplastic Thyroid Cancer. Cancer Control, 13, 119128. 
[22] Kurukahvecioglu, O., Ege, B., Poyraz, A., Tezel, E. and Taneri, F. (2007) Anaplastic Thyroid Carcinoma with Long Term Survival after Combined Treatment: Case Report. Endocrine Regulations, 41, 41-44.

[23] Liu, A.H., Juan, L.Y., Yang, A.H., Chen, H.S. and Lin, H.D. (2006) Anaplastic Thyroid Cancer with Uncommon Long-Term Survival. Journal of the Chinese Medical Association, 69, 489-491. http://dx.doi.org/10.1016/S1726-4901(09)70314-4

[24] Akaishi, J., Sugino, K., Kitagawa, W., Nagahama, M., Kameyama, K., Shimizu, K., et al. (2011) Prognostic Factors and Treatment Outcomes of 100 Cases of Anaplastic Thyroid Carcinoma. Thyroid, 21, 1183-1189. http://dx.doi.org/10.1089/thy.2010.0332

[25] Kanaseki, T., Harabuchi, Y., Wakashima, J., Asakura, K., Kataura, A. and Satoh, M. (1999) A Case of Anaplastic Thyroid Carcinoma Surviving Disease Free for over 2 Years. Auris Nasus Larynx, 26, 217-220. http://dx.doi.org/10.1016/S0385-8146(98)00074-1

[26] Pichardo-Lowden, A., Durvesh, S., Douglas, S., Todd, W., Bruno, M. and Goldenberg, D. (2009) Anaplastic Thyroid Carcinoma in a Young Woman: A Rare Case of Survival. Thyroid, 19, 775-779. http://dx.doi.org/10.1089/thy.2009.0025

[27] Shinohara, S., Kikuchi, M., Naito, Y., Fujiwara, K., Hori, S., Tona, Y., et al. (2009) Successful Treatment of Locally Advanced Anaplastic Thyroid Carcinoma by Chemotherapy and Hyperfractionated Radiotherapy. Auris Nasus Larynx, 36, 729-732. http://dx.doi.org/10.1016/j.anl.2009.02.001

[28] Noguchi, H., Yamashita, H., Murakami, T., Hirai, K., Noguchi, Y., Maruta, J., et al. (2009) Successful Treatment of Anaplastic Thyroid Carcinoma with a Combination of Oral Valproic Acid, Chemotherapy, Radiation and Surgery. Endocrine Journal, 56, 245-249. http://dx.doi.org/10.1507/endocrj.K08E-016

[29] De Crevoisier, R., Baudin, E., Bachelot, A., Leboulleux, S., Travagli, J.-P., Caillou, B. and Schlumberger, M. (2004) Combined Treatment of Anaplastic Thyroid Carcinoma with Surgery, Chemotherapy, and Hyperfractionated Accelerated External Radiotherapy. International Journal of Radiation Oncology*Biology*Physics, 60, 1137-1143. http://dx.doi.org/10.1016/j.ijrobp.2004.05.032

[30] Shin, D.H., Mark, E.J., Suen, H.C. and Grillo, H.C. (1993) Pathologic Staging of Papillary Carcinoma of the Thyroid with Airway Invasion Based on the Anatomic Manner of Extension to the Trachea: A Clinicopathologic Study Based on 22 Patients Who Underwent Thyroidectomy and Airway Resection. Human Pathology, 24, 866-870. http://dx.doi.org/10.1016/0046-8177(93)90136-5

[31] Olthof, M., Persoon, A.C., Plukker, J.T., van der Wal, J.E. and Links, T.P. (2008) Anaplastic Thyroid Carcinoma with Rhabdomyoblastic Differentiation: A Case Report with a Good Clinical Outcome. Endocrine Pathology, 19, 62-65. http://dx.doi.org/10.1007/s12022-008-9017-3

[32] Kihara, M., Miyauchi, A., Yamauchi, A. and Yokomise, H. (2004) Prognostic Factors of Anaplastic Thyroid Carcinoma. Surgery Today, 34, 394-398. http://dx.doi.org/10.1007/s00595-003-2737-6

[33] Kim, T.Y., Kim, K.W., Jung, T.S., Kim, J.M., Kim, S.W., Chung, K.-W., et al. (2007) Prognostic Factors for Korean Patients with Anaplastic Thyroid Carcinoma. Head Neck, 29, 765-772. http://dx.doi.org/10.1002/hed.20578

[34] Siironen, P., Hagström, J., Mäenpää, H.O., Louhimo, J., Heikkilä, A., Heiskanen, I., et al. (2010) Anaplastic and Poorly Differentiated Thyroid Carcinoma: Therapeutic Strategies and Treatment Outcome of 52 Consecutive Patients. Oncology, 79, 400-408. http://dx.doi.org/10.1159/000322640

[35] Ito, K., Hanamura, T., Murayama, K., Okada, T., Watanabe, T., Harada, M., et al. (2012) Multimodality Therapeutic Outcomes in Anaplastic Thyroid Carcinoma: Improved Survival in Subgroups of Patients with Localized Primary Tumours. Head Neck, 34, 230-237. http://dx.doi.org/10.1002/hed.21721

[36] Rodriguez, J.M., Piñero, A., Ortiz, S., Moreno, A., Sola, J., Soria, T., et al. (2000) Clinical and Histological Differences in Anaplastic Thyroid Carcinoma. European Journal of Surgery, 166, 34-38. 